\title{
“She Dared to Reprove Her Father:" Miriam's Image as a Female Prophet in Rabbinic Interpretation
}

\author{
Agnethe Siquans (University of Vienna)
}

This article discusses rabbinic references to Miriam's prophetic speaking and the question of her value as a female prophet. The focus is on specific passages in the Babylonian Talmud Sotah and Exodus Rabbah and their portrait of Miriam as a female prophet. Other rabbinic texts add some further aspects to this picture. In contrast to the biblical accounts in Exod 2 and 15, the rabbinic texts transfer Miriam's prophecy to her childhood and focus on Moses alone. Furthermore, Miriam's prophecy is restricted to family affairs and the birth of children, in particular Moses's birth. She is elaborately depicted as a motherly and caring midwife. Rabbinic interpretations of Num 12 criticize her speech as improper for a woman. Thus, Miriam's image as a female prophet in rabbinic texts remains ambivalent, estimating her role as a prophet and, at the same time, criticizing her as a woman and restricting her to the "female" sphere of family and care.

\section{Introduction}

Prophetic speaking, in particular if exercised in public, presumes authority and, reciprocally, ascribes authority to the prophet, an authority grounded in the divine authority that is assumed to underlie his or her speech. ${ }^{1}$ Biblical prophets are supposed to speak with divine authority, and for this reason their speech is highly valued. ${ }^{2}$ When biblical prophets are female, however, their authority and legitimacy are often called into question and diminished, for the reason that they are women. Ancient Greco-Roman society ${ }^{3}$ did not value the public speech of women. ${ }^{4}$ Rabbinic interpretive traditions, dating

1 For a definition of prophecy see below, section 3.1.

2 This is true for the tradition and reception of biblical prophetic texts. The question whether a prophet was accepted and acknowledged in his or her lifetime (if he or she can even be regarded as an historical person) is a different one.

3 According to G. Stemberger, Einführung in die Judaistik (München: C. H. Beck, 2002), 71, the rabbinic period lasts from the destruction of the temple (70 C.E.) until the Arab expansion in the seventh century; in a broader sense it can extend even to 1099 (the First Crusade). The Greco-Roman world of the first few centuries C. E. can be regarded as the cultural context of the early rabbinic period (tannaitic and amoraic periods). For this context see below, section 2.2.

4 For more details see below, section 2.2. For ideas about women and women's status in Greco-Roman society (in different periods) see, for example, G. Clark, Women in Late Antiquity: Pagan and Christian Lifestyles (Oxford: Oxford University Press, 1994); T. Ilan, Jewish Women in Greco-Roman Palestine: An Inquiry into Image and Status (TSAJ 44; Tübingen; Mohr Siebeck, 1995); A. Jensen, Gottes selbstbewusste Töchter: Frauenemanzipation im frühen Christentum? (Freiburg i. Br.: Herder, 1992); P. L’Hermite-Leclercq, L'Église et les femmes dans l'Occident chrétien des origins à la fin du Moyen Age (Turnhout: Brepols, 1997); C. Sourvinou-Inwood, "Male and Female, Public and Private, Ancient and Modern," in Pandora: Women in Classical Greece (eds. E. D. Reeder and S. C. Humphreys; Princeton, N. J.: Princeton University Press, 1995), 111-20; E.M. Synek, “The Church as 'oikos': Main Ca- 
to the Tannaitic and Amoraic periods, originated within this society and at least to some extent participate in its ideas. Thus, the biblical female prophets are valued on the one hand (as they are authorized by God or his spirit), but on the other hand, their activity is regarded critically. ${ }^{5}$ This paper will discuss rabbinic references to Miriam's prophetic speaking and the question of her value as a female prophet.

Miriam is one of the most frequently mentioned and most prominent biblical women in ancient Jewish reception of the Scriptures. ${ }^{6}$ Rabbinic midrash interprets Miriam's life and prophetic activity according to rabbinic ideas about women and men, about character, and about Jewish life. ${ }^{7}$ Rabbinic midrash creates for us a new story about Miriam, even if a very fragmentary and selective one. As Devorah Steinmetz writes: "The details of midrashic exegesis ... must always be understood as telling a specific story or offering a broad interpretation of the biblical narrative, in addition to providing a solution for a local exegetical problem."

This article focuses on Miriam's depiction as a female prophet in rabbinic texts, with a focus on $b$. Sotah and Exodus Rabbah. ${ }^{9}$ These texts include extensive passages that deal with Miriam and her prophecy. They are chosen for this

nonical Consequences," in Gender and Religion (eds. K.E. Børresen et al.; Rome: Carocci, 2001), 143-53; B. Wagner-Hasel, "Das Diktum der Philosophen: Der Ausschluss der Frauen aus der Politik und die Furcht vor der Frauenherrschaft," in Frauenwelten in der Antike: Geschlechterordnung und weibliche Lebenspraxis (eds. T. Späth and B. Wagner-Hasel; Stuttgart: Metzler, 2000), 198-217.

5 See e.g., L.L. Bronner, "Biblical Prophetesses Through Rabbinic Lenses," Judaism 40 (1990): 171-83; for early Christian interpretation, see A. Siquans, "Gender und prophetisches Reden: Mirjam und Debora in der patristischen Reflexion," Annali di studi religiosi 9 (2008): 279-89.

6 For the Second Temple period, see H. Tervanotko, Denying her Voice: The Figure of Miriam in Ancient Jewish Literature (JAJSup; Göttingen: Vandenhoeck \& Ruprecht, forthcoming); eadem, "The Hope of the Enemy has Perished': The Figure of Miriam in the Qumran Library," in From Qumran to Aleppo (eds. A. Lange et al.; FRLANT 230; Göttingen: Vandenhoeck \& Ruprecht, 2009), 156-75; S. W. Crawford, "Traditions about Miriam in the Qumran Scrolls," Studies in Jewish Civilization 14 (2003): 33-44. For Miriam's patristic reception, see A. Siquans, Die alttestamentlichen Prophetinnen in der patristischen Rezeption: Texte - Kontexte - Hermeneutik (HBS 65; Freiburg i. Br.: Herder, 2011).

7 Cf. D. Steinmetz, “A Portrait of Miriam in Rabbinic Midrash," Prooftexts 8 (1988): 35-65. For Miriam in the Hebrew Bible and midrash, see also N. J. Cohen, "Miriam’s Song: A Modern Midrashic Reading," Judaism 33 (1984): 179-90.

8 Steinmetz, "Portrait," 36. See also her methodological considerations about characterization in midrash.

9 This paper does not intend to give a comprehensive picture of Miriam's character, but focuses on the response to, or rather, criticism of her prophecy. Following G. Stemberger, Einleitung in Talmud und Midrasch (8th ed.; Munich: Beck, 1992), 304, this article assumes that Exod. Rab. used material from b. Sotah; cf. A. Shinan (ed.), Midrash Shemot Rabbah: Chapters 1-14: A Critical Edition Based on a Jerusalem Manuscript with Variants, Commentary and Introduction (Tel Aviv: Dvir 1984), 19-20. Further questions about sources and their relationships will not be discussed. The focus is on the two texts and their different perspectives on Miriam's prophecy. For further parallels see Steinmetz, "Portrait." 
examination because of their quite detailed explanation of the biblical text, primarily Exod 1-2 where Miriam is first mentioned and in which context her prophecy is discussed by the Rabbis. B. Sotah is one of the earliest rabbinic texts dealing with Miriam. ${ }^{10}$ The first part of the midrash Shemot Rabbah (on Exod 1-10) was redacted in the tenth century, although it incorporates earlier traditions. ${ }^{11}$ It represents a later stage of interpretation, is more elaborate, and therefore is fit to illustrate how the image of Miriam the female prophet developed over the centuries. In this paper, the interpretations of Exod 1-2 in b. Sotah and Exodus Rabbah are analyzed in detail, whereas other rabbinic texts complement this picture and occasionally add some additional aspects. Miriam as a female prophet is highly valued as one of Israel's famous ancestresses. Yet, her speaking is criticized more or less openly, due to objections concerning women's public speech, which rabbinic texts share with their pagan and Christian surroundings.

I begin with some introductory remarks that shed some light on the biblical texts that deal with Miriam and her prophecy (2.1) as well as on the question of the ancient attitudes toward women's public speaking as the broader cultural context of the rabbinic interpretation (2.2). I then consider Miriam's prophetic speaking and its interpretation in several shorter passages of rabbinic texts (3.1). I further examine the image of Miriam as a female prophet in $b$. Sotah (4) and in Exodus Rabbah (5). Finally, some conclusions about the appraisal of her prophetic speech in these texts will be drawn (6).

\section{Biblical Text and Cultural Context}

\subsection{Miriam's Prophetic Speaking in Biblical Texts}

Miriam is first mentioned by name in Exod 15:20, and further appears in Num 12; 20:1; 26:59; 1 Chr 5:29; Deut 24:9; Mic 6:4. ${ }^{12}$ She is only quoted directly in two of these passages (Exod 15:21; Num 12:2). Exodus 15:21 quotes the famous song she intones at the Red Sea:שירו לאדני כי גאה גאה סוס ורכבו רמה בים. In Exod 15:20 Miriam is called נביאה: "female prophet." It is the only time this designation is used for her in the Hebrew Bible. The brevity of her prophecy is remarkable in comparison to the words of most of her male colleagues in the Hebrew Bible. Only a few words of this female prophet are preserved. On the one hand, the quotation of her words can be regarded as a sign of esteem,

10 The Mekhilta, dating from the second half of the third century (cf. Stemberger, Einleitung, 251-53), has only a few scattered comments on Miriam.

11 Cf. Stemberger, Einleitung, 304.

12 For Miriam in the biblical texts see e.g., P. Trible, "Bringing Miriam out of the Shadows," in A Feminist Companion to Exodus to Deuteronomy (ed. A. Brenner; Feminist Companion to the Bible 6; Sheffield: Sheffield Academic Press, 1994), 166-86. On Num 12, see especially N. Graetz, "Did Miriam Talk Too Much?" in Unlocking the Garden: A Feminist Jewish Look at the Bible, Midrash and God (ed. N. Graetz; Piscataway, N. J.: Gorgias Press, 2005), 41-51. 
on the other hand its brevity lessens this appreciation. Either way, the Torah allows Miriam to speak. As will be shown below, later interpreters are much more reluctant to accept women speaking.

In Num 12 the issue of prophecy is also at stake. Miriam, together with her brother Aaron, criticizes Moses: ותדבר מרים ואהרן במשה (Num 12:1). They ask: "Has the Lord indeed spoken only through Moses? Has he not spoken through us also?" (Num 12:2). ${ }^{13}$ This criticism of Moses is uttered by both Miriam and Aaron, but the initial verb in verse 1 identifies Miriam as the spokesperson. Accordingly, only Miriam is punished. She receives a skin disease, ${ }^{14}$ which is quite a hard punishment, and God makes clear that Moses has an extraordinary prophetic authority. The text does not deny prophecy to Miriam (and Aaron) completely. In verses 6-8, God speaks to Moses and confirms his exceptional prophecy and his special closeness to God whereas all other prophets are restricted to the usual forms of revelation, i. e., visions and dreams. Miriam is one of these "ordinary" prophets, who must not dare to criticize Moses (v. 8), and whose punishment is withdrawn only after Aaron's and Moses' intercession for her. Thus, the biblical image of Miriam the female prophet is ambivalent. ${ }^{15}$

\subsection{Criticism of Female Speech in Ancient Texts}

In several ancient texts, Greek and Roman, Christian, and Jewish, objections against women speaking in public or women speaking in general can be found. Some examples will illustrate this idea.

Plutarch says about women: "Not only the arm of the virtuous woman, but her speech as well, ought to be not for the public, and she ought to be modest and guarded about saying anything in the hearing of outsiders, since it is an exposure of herself ..." 16 The historian Livy has Cato ask: "What kind of behavior is this? Running around in public, blocking streets, and speaking to other women's husbands! Could you not have asked your husband the same thing at home?"17

13 All biblical quotations in English are from the RSV.

14 The Hebrew word צרעת denotes a skin disease: cf. e.g., D. J.A. Clines, The Concise Dictionary of Classical Hebrew (Sheffield: Sheffield Phoenix Press, 2009) 385: "skin disease, with scaling as one of its symptoms; not leprosy." The current English Bibles translate with "leprosy." BDB also translates as "leprosy."

15 Steinmetz, "Portrait," 56, calls the biblical portrait of Miriam ambiguous, whereas her midrashic portrayal is ambivalent. In my opinion, the biblical portrait is also ambivalent (at least concerning her prophecy), because two distinct stories value her prophecy differently.

16 Plutarch, "Advice to Bride and Groom 31," in F.C. Babbitt, Plutarch's Moralia in Fifteen Volumes (London: William Heinemann Ltd.; Cambridge, Mass.: Harvard University Press, 1962), 2.321-22.

17 Titus Livius, $A b$ urbe condita 34.2.9; English translation quoted from C. Forbes, Prophecy and Inspired Speech in Early Christianity and its Hellenistic Environment (WUNT 2.75; Tübingen: Mohr Siebeck 1995), 275; E. Schüssler Fiorenza, In Memory of Her: A Feminist Theological Reconstruction of Christian Origins (London: SCM Press, 1983), 231-32. 
Women were supposed not to speak in public and above all not to (other) men. Women were admonished to speak to their husbands or through their husbands (or brothers, fathers, or other relatives). Interpreters of Scripture, Jewish and Christian, took up this notion. They shared these objections against female speech with their pagan surroundings. ${ }^{18}$ Women's (public) speaking or even contradicting men was considered unnatural and also against God's creation and his will. Female prophecy became an ambivalent issue, because it implies public speech. ${ }^{19}$

This notion also extends to female speech in general, as the following text may illustrate. Genesis Rabbah preserves a well-known passage that explains why woman was created from the man's rib (Gen. Rab. 18.2). ${ }^{20}$ The text mentions parts of the body from which woman was not created and then gives biblical examples pointing to the problems woman's creation nevertheless caused: God did not create the woman from the head or the eye ${ }^{21}$ nor "from the ear, yet she is an eavesdropper" like Sarah; nor from the mouth, yet she is "talkative" like Miriam (quoting Num 12:1); ${ }^{22}$ nor from the heart, yet she is prone to jealousy (like Rachel); nor "from the hand, yet she is one who touches everything" (like Rachel, again); and finally not from the foot, yet she is walking about (like Dinah). ${ }^{23}$ Thus, for Genesis Rabbah the speaking of women is negative, as the cited example of Miriam shows, and it is deeply rooted in women's nature.

This very motif is taken up by the Christian bishop Ephrem the Syrian who combines it with the Pauline commandment that women are not to speak in the churches.

But let us say, when [God] built and formed that rib, He fashioned it with all that was necessary. But let us also say, that if [God] had created her from the ground as [He has created] Adam, she perhaps would have usurped the magnificence of his authority.

18 Cf. Forbes, Prophecy, 274-75; G. Strecker and U. Schnelle (eds.), Neuer Wettstein: Texte zum Neuen Testament aus Griechentum und Hellenismus 2,1 (Berlin: de Gruyter, 1996), 385-88.

19 Paul's admonitions in 1 Cor 11-14 are an outstanding example for these ideas and their obvious challenge by the Corinthian women. Cf. e. g., Schüssler Fiorenza, Memory, 226-33; Forbes, Prophecy, 251-78; A. Clark Wire, The Corinthian Women Prophets: A Reconstruction Through Paul's Rhetoric (Minneapolis: Fortress, 1990); K. L. King, "Voices of the Spirit: Exercising Power, Embracing Responsibility," in Women Preachers and Prophets Through Two Millennia of Christianity (eds. B. Mayne Kienzle and P. J. Walker; Berkeley: University of California Press, 1998), 335-43; L. Schottroff, Lydias ungeduldige Schwestern: Feministische Sozialgeschichte des frühen Christentums (Gütersloh: Kaiser et al., 1994).

20 Cf. J. Theodor and Ch. Albeck, eds., Midrash Bereshit Rabba 1: Parashah 1-47 (Veröffentlichungen der Akademie für die Wissenschaft des Judentums; Jerusalem: Wahrmann Books, 1965), 162-63.

21 No particular biblical woman is mentioned in connection with the head or the eye; there is just a quotation of Isa 3:16.

22 The mouth and thus Miriam are not mentioned in all manuscripts of Gen. Rab., although the mouth is included in the preceding list of body parts.

23 Translation follows H. Freedman, Genesis, vol. 1 of Midrash Rabbah (10 vols.; ed. H. Freedman; London: Soncino Press, $1983^{3}$ ), 1.142. 
Nor did [God] take [Eve] from [Adam's] head, lest perchance some boldness come upon her. For just as all speech is of the head, all silence is in the rib, for which reason the Apostle commanded and said, Lest she speak in Church as she spoke in the Garden. But perhaps women are grieved when they hear of their submission; rather, let them be joyful for it is greater for them than for Adam. For Adam was created and fashioned from inert soil, but [women] were taken from a living speaking being and their souls shall be exalted. For to the degree that Eve, their mother, had brought disorder into the lives of humanity, similarly the Virgin Mary, who gave birth to Christ, has straightened out and reestablished the living things of the world. ${ }^{24}$

For the Pauline tradition, women's subordination is founded in creation (cf. 1 Cor 11, 1 Tim 2:13): "For man was not made from woman, but woman from man. Neither was man created for woman, but woman for man" (1 Cor 11:8-9).

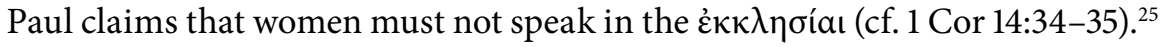
Ephrem quotes from 1 Cor 14:34 and connects this verse to the narrative of Gen 3 (cf. 1 Tim 2:14). Apparently, Ephrem shares the rabbinic reservation concerning women's speech. ${ }^{26}$

The above quoted texts all presume women's subordination to men. The idea that women should not talk too much or not in public is part of this subordination - as these and many other ancient authors understood it. Yet these texts do not prove that women did not speak in public - to the contrary, they indicate that it was necessary to prevent them from doing so. Thraede suggests that texts like Livy's and Plutarch's are ideological and far from reality. ${ }^{27}$ They are prescriptions rather than descriptions. He claims that early Christianity referred to ideals that were actually already outdated. ${ }^{28}$ He points to the fact that likewise in late ancient Judaism ideal and reality were drifting apart. ${ }^{29}$

24 E.C. Mathews, The Armenian Commentary on Genesis attributed to Ephrem the Syrian (CSCO 573; Leuven: Peeters, 1998), 19.

25 Whether these two verses are originally Pauline or a later interpolation is disputed. See for example Schüssler Fiorenza, Memory, 230, who states that the verses "cannot be excluded on textual-critical grounds," and M. Crüsemann, "Unrettbar frauenfeindlich: Der Kampf um das Wort von Frauen in 1 Kor 14,(33b)34-35 im Spiegel antijudaistischer Elemente der Auslegung," in Von der Wurzel getragen: Christlich-feministische Exegese in Auseinandersetzung mit Antijudaismus (ed. L. Schottroff; Leiden: Brill, 1996), 199-223, who argues against the Pauline origin of the passage. In fact, this does not matter with regard to the reception history, during which these verses were read as an authoritative prescription of Paul.

26 He does not mention Miriam and the other women from the Hebrew Bible, other than Eve and Mary, and adds a Pauline quotation. However, the interpretation of the creation account has a similar tendency.

27 See K. Thraede, "Frau," RAC 8:198-269. He polemically speaks of a "conservative ideology of the nest," i.e., the house, as an ideal in contrast to social reality: "Diese konservative 'Nestideologie' mit dem betont erosfeindlichen Schema der röm[ischen] Matrone deckt sich mit der gesellschaftlichen Wirklichkeit so wenig wie mit der politischen ... u[nd] wird durch die Quellen bereits republikanischer Zeit als Wunschbild erwiesen"; Thraede, "Frau," 215.

28 Thraede, "Frau," 240. Nevertheless, it points to the fact that ideal and reality were also drifting apart in late ancient Judaism.

29 Thraede, "Frau," 224-27. His passage about "Spätjudentum" (!) is short in comparison to the chapter about Christianity and contains problematic statements. 
Women's public speaking was objectionable to ancient Greeks, Romans, Jews, and Christians alike. But, of course, "prophecy is public." ${ }^{30}$ Miriam, for instance, speaks in the presence of the entire people of Israel (cf. Exod 15:2021). Huldah speaks to the officials sent by the king (cf. 2 Kgs 22:14-20). Prophets like Jeremiah, Amos, Isaiah, and others also speak to the people (or a particular group of them) or to the king and his officials. Therefore, the speech of biblical female prophets was evaluated ambivalently and with some reservation.

\section{Miriam's Prophecy}

\subsection{What is Miriam's Prophecy?}

Exodus 15:20 does not explicitly tell the readers what Miriam's prophecy actually was. She is called a נביאה and is depicted as drumming and singing, leading the Israelite women in dance. This possible gap or obscurity in the biblical text has motivated interpreters over time to ask and answer why Miriam is called a female prophet. In the following, a contemporary scholarly and an ancient answer to this question are discussed to clarify the question of Miriam's prophecy. ${ }^{31}$

Irmtraud Fischer defines prophecy in the succession of Moses and Miriam as the mediation of YHWH's Torah to the people, the interpretation and actualization of the Torah..$^{32}$ Israelite prophets, according to Deut 18:18, have to enunciate God's words. Like Moses, they communicate them to the people and

30 Cf. Forbes, Prophecy, 220.

31 What biblical or Israelite prophecy was is indeed not easy to define: "No comprehensive definition of an Israelite prophet is possible. The persons conventionally included in this category appear to have manifested great diversity of character and function. They are referred to by a number of terms ... In general, it may be said that prophets were men or women believed to be recipients through audition, vision, or dream of divine messages that they passed on to others by means of speech or symbolic action" (R. N. Whybray, "Prophets," in The Oxford Companion to the Bible [eds. B. M. Metzger and M.D. Coogan; New York: Oxford University Press, 1993], 620-22, 620). J. Stökl, "Gender 'Ambiguity' in Ancient Near Eastern Prophecy? A Reassessment of the Data behind a Popular Theory," in Prophets Male and Female: Gender and Prophecy in the Hebrew Bible, the Eastern Mediterranean, and the Ancient Near East (eds. J. Stökl and C.L. Carvalho; Atlanta: Society of Biblical Literature, 2013), 59-79, 72, identifies prophecy in even more general terms: "Transmission of divine messages to human addressees." The two definitions of prophecy that will be assumed in the following discussion correspond with this general setting. Fischer's determination of Miriam's prophecy as mediation between $\mathrm{YHWH}$ and Israel and the idea of prophecy as prediction of future events are two particular ways of transmitting divine messages to humans.

32 Cf. I. Fischer, Gotteskünderinnen: Zu einer geschlechterfairen Deutung des Phänomens der Prophetie und der Prophetinnen in der Hebräischen Bibel (Stuttgart: Kohlhammer, 2002), 53-60, 74-75. See also R. Kessler, "Mirjam und die Prophetie der Perserzeit," in Gott an den Rändern: Sozialgeschichtliche Perspektiven auf die Bibel (eds. U. Bail and R. Jost; Gütersloh: Kaiser, Gütersloher Verlag-Haus, 1996) 64-72; K. Butting, Prophetinnen gefragt: Die Bedeutung der Prophetinnen im Kanon aus Tora und Prophetie (Erev-Rav-Hefte Biblischfeministische Texte 3; Wittingen: Erev-Rav, 2001). 
communicate the people's answer to God (cf.e.g., Exod 19:8). Correspondingly, Fischer understands Miriam's Song at the Sea as the prophetic answer to YHWH's salvation of Israel and thus as her prophecy. ${ }^{33}$ Fischer dates Miriam's song to the Persian period. ${ }^{34}$ Reinhold Then has shown that, in this period, prophecy and cultic music are closely connected with each other (cf. $1 \mathrm{Chr}$ 25:5-6). ${ }^{35}$ Female singers are mentioned in Ezra 2:65 and Neh 7:67. Miriam's words in Exod 15:21 can be understood within this context: Miriam represents prophecy, in the form in which it was performed in the Persian period. The biblical text presents her song as prophetic and Miriam herself as mediator between God and his people. According to the definition in Deut 18, prophecy was primarily understood as mediation.

From the Hellenistic period onward, prophecy was increasingly seen as the prediction of future events. ${ }^{36}$ For instance, in the Liber Antiquitatum Biblicarum (L.A. B.) by Pseudo-Philo, ${ }^{37}$ Miriam's prophecy is situated in her childhood. She predicts Moses' birth. Yet, her parents do not believe her:

The spirit of God came upon Miriam one night, and she saw a dream and reported it to her parents in the morning, saying, "I had a vision this night, and behold a man was standing in a linen garment and he said to me, 'Go and say to your parents, "Behold the child who will be born of you will be cast forth into the water; likewise through him the water will be dried up. And I will work signs through him and save my people, and he will exercise leadership always."' When Miriam reported her dream, her parents did not believe her. ${ }^{38}$

In this passage, Miriam's title נביאה, which only appears in Exod 15:20, is drawn into the narration of Moses' birth (Exod 2). That implies, of course, that the sister mentioned in Exod 2:4 is identical with Miriam. ${ }^{39}$ The narrative about Moses' birth and wondrous salvation in Exod 2 where his future mission is already visible invites further elaboration. The sister's role lacks clarity in the biblical text. Why does she stand at a distance, watching the basket with

33 Cf. Fischer, Gotteskünderinnen, 66.

34 For arguments cf. Fischer, Gotteskünderinnen, 73-75. Kessler and Butting (see n. 32) also prefer this date.

35 R. Then, "Gibt es denn keinen mehr unter den Propheten?": Zum Fortgang der alttestamentlichen Prophetie in frühjüdischer Zeit (Beiträge zur Erforschung des Alten Testaments und des antiken Judentums 22; Frankfurt a. M.: Lang, 1990), esp. 264-65 (short resumé).

36 Prediction of future events is a particular way of transmitting God's word to humans, of course.

37 J. Strugnell, "Philo (Pseudo-)Liber Antiquitatum Biblicarum," EncJud ${ }^{2} 16$ (2007): 58-59 dates this text to shortly after 70 C. E.; the extant text is a Latin translation of a Greek text, which itself is a translation of a Hebrew text.

38 H. Jacobson, ed., A Commentary on Pseudo-Philo's Liber Antiquitatum Biblicarum with Latin Text and English Translation 1 (AGJU 31.1; Leiden: Brill, 1996), 105. For a discussion of Miriam's image in L.A.B. see Tervanotko, Denying, 251-61.

39 The sister is not mentioned by name in Exod 2. The name Miriam first occurs in Exod 15:20. As there is no other sister mentioned in the Hebrew Bible than Miriam, it seems logical that "the sister" in Exod 2 was identified with her. Nevertheless, this is already an interpretation, because the text itself does not clarify the sister's identity. 
her brother in it? The authors of L.A.B., knew, of course, that she was called a female prophet later in the book. As they apparently did not consider her song in Exod 15:21 to be a prophecy - what could that prophecy be? There is no prediction in Exod 15:2--they therefore considered Exod 2 to be a possible place for her prophetic activity. In line with the focus on Moses in Exod 2 (as well as in the whole book and in later tradition), Miriam's prophecy had to refer to him. Incidentally, he is the only one mentioned by name in the birth narrative of Exod 2:1-10. The L.A.B. therefore integrated Miriam's prophecy into the interpretation of Exod 2.

In L. A. B.'s account, Miriam is overcome by God's spirit, and she has a prophetic dream. This can be read as an allusion to Num 12:6, as Hanna Tervanotko has suggested: ${ }^{40}$ "If there is a prophet among you, I the Lord make myself known to him in a vision, I speak with him in a dream." If this can be assumed, the Hebrew Bible's disapproval of Miriam is subtly implied here. Miriam's prophecy is in fact connected with the censure of her speaking against Moses. As she and her prophecy are subordinated to Moses in this text, her prophecy is accepted - but only under this condition. The L. A. B. tradition about Miriam's prophecy and its situation in her early childhood recurs in later rabbinic texts, as will be shown below.

\subsection{Miriam's (Prophetic) Speaking in Rabbinic Interpretations of Numbers 12}

\subsubsection{Sifre Zuta and Sifre Numbers}

Sifre Zuta (Beha'alotekha $\$ 12$ ) as well as the Sifre Numbers (Beha'alotekha $\$ \$ 96-110)$ try to explain Miriam's problematic behavior and, above all, her punishment by "leprosy." ${ }^{41}$ Sifre Zuta justifies Miriam's illness with reference to her "bad tongue" (לשון הרע). She started the communication, and Aaron

40 H. Tervanotko, "Speaking in Dreams: The Figure of Miriam and Prophecy," in Prophets Male and Female: Gender and Prophecy in the Hebrew Bible, the Eastern Mediterranean, and the Ancient Near East (ed. J. Stökl and C. L. Carvalho; Ancient Israel and Its Literature 15; Atlanta: Society of Biblical Literature, 2013), 147-67. She argues that Num 12 as well as L.A.B. and the Visions of Amram assume that Miriam is a visionary who receives divine revelations through dreams.

41 According to D. Börner-Klein, Tannaitische Midraschim 3A: Der Midrasch Sifre Zuta (Rabbinische Texte, Reihe 2; Stuttgart: Kohlhammer, 2002), 2, the traditions in Sifre Zuta go back to the second or early third century. Sifre is dated to the third century. Both are thus among the oldest rabbinic writings: See D. Börner-Klein, Tannaitische Midraschim 3: Der Midrasch Sifre zu Numeri (Rabbinische Texte, Reihe 2; Stuttgart: Kohlhammer, 1997), 389. The oldest known manuscript of Sifre is dated to the tenth or early eleventh century (MS Vatican 32). Börner-Klein's two volumes contain a German translation of Sifre Zuta and the Sifre on Numbers. Hebrew text: H.S. Horovitz, ed., Siphre ad Numeros adjecto Siphre zutta: Cum variis lectionibus et adnotationibus (Leipzig 1917; reprint Jerusalem: Wahrmann Books, 1966).

42 Horovitz, Siphre, 274. 
joined her. This follows from Num 12:1: ותדבר מרים ואהרן. Another explanation traces the beginning of this affair back to Zippora who, according to R. Shimon, in fact started the communication. Sifre Zuta mentions Moses' separation from Zippora as the reason for the dispute. The explanation of Num 12:9 makes it clear that God's wrath hit both, Miriam and Aaron, but that Aaron was immediately healed. The midrash then asks why Scripture reveals only Miriam's punishment whereas Aaron's is merely suggested (ולמה פרסם

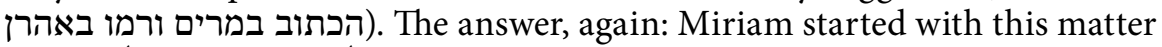
) though not as such, but only because she spoke before Aaron, which implicitly means that she did not respect her brother's primacy. Sifre Zuta also provides the words that Miriam and Aaron spoke, following Num 12:2. They emphatically refer to their own prophecy. The midrash in no way criticizes this prophecy, neither the fact nor the content. It only criticizes Miriam's precedence over Aaron.

The Sifre Numbers also states that both Miriam and Aaron spoke, but that Miriam was the one who began. ${ }^{44}$ The singular verb hints at Miriam as the leader in this affair. Immediately after that, the midrash excuses her: She usually did not speak before Aaron. She only did so here because it was necessary in this particular situation, which is explained in the following: Miriam acted in support of Zippora who told her that Moses abstained from procreation. Thus, Miriam's intention was not to criticize her brother but to promote fertility and multiplication (commanded in Gen 1:28). ${ }^{45}$ Additionally, the midrash maintains that Miriam spoke to Aaron only "in private" (עצמה). ${ }^{46}$ Hence, Moses did not hear her words and she spoke "to his credit."

Now it is an argument a fortiori: if Miriam, who intended to speak against her brother not to his detriment but to his credit, and not to lessen procreation but to increase it, and who spoke only in private, yet she was punished, if someone intends to speak ill of his fellow and not in praise, to diminish and not to increase procreation, and speaks not in private but among others - how much the more so [will such a one be punished] $!^{47}$

The Sifre's image of Miriam, therefore, is quite positive. Her punishment is dealt with rather implicitly. Yet, the text clearly shows that a woman's speaking is considered to be problematic, as the emphasis on its private character shows very well.

43 Horovitz, Siphre, 276.

44 Hebrew text: Horovitz, Siphre, 97-105. English translation: J. Neusner, The Components of the Rabbinic Documents. From the Whole to the Parts. XII. Sifré to Numbers, part 2 (South Florida Academic Commentary Series 105; Atlanta: Scholars Press, 1998), 61-76.

45 See also Deuteronomy Rabbah 6.11.

46 Horovitz, Siphre, 98; English: Neusner, Sifré, 63. It is interesting to observe that Miriam speaks to Aaron and not together with Aaron, as Num 12:1 suggests.

47 See Neusner, Sifré, 63. The next section discusses the case of Uzziah the king, who also was punished by a skin disease. Miriam and Uzziah thus often occur together. 


\subsubsection{Midrash Tanḥuma}

Midrash Tanhuma has the same reasoning in slightly different words (Metsora', Lev 5:6):

(Lev 14:2): This shall be the law of the leper. Whoever speaks slander concerning his fellow will have leprosy come upon him. From where have you learned it? From Miriam.] See what is written about Miriam (in Num 12:1): Then Miriam and Aaron spoke against Moses. Therefore (in v. 10): Then Aaron turned unto Miriam; and there was [Miriam] with leprosy like the snow. What is written elsewhere (in Deut 24:9)? Remember what the Lord your God did to Miriam. And what did she say against Moses? She said: Moses took (natal) a wife but ceased (batel) from being fruitful and multiplying. What did the Holy One do to them? He appeared to them, and they needed an immersion. Thus it is stated (in Num 12:4): Then the Lord suddenly spoke unto Moses; unto Aaron; and unto Miriam. What is the meaning of suddenly? That when he appeared unto them, they had need for water suddenly. He spoke to them, and thus they had need for water. And I am speaking with you. Immediately Miriam became stricken with leprosy, as stated (in Num 12:10): And there was [Miriam] with leprosy like the snow. Moreover, are not 〈these $\rangle$ words an argument a fortiori (qal wahomer)? For if Miriam had this happen, when she only spoke against her beloved brother when he was absent and was only intending to return him to his wife, how much the more so in the case of one who utters slander against his colleague? What is written above on the matter (in Deut 24:8)? Take care with the plague of leprosy (to watch diligently and do according to all that the priests and Levites shall teach.) So the hand of the Holy One also afflicted Aaron with it, when he was high priest. Thus it is stated (in Num 12:9): And the anger of the Lord was kindled against them, 〈i. e.〉 against Aaron and against Miriam. Aaron, however, was healed immediately; but Miriam, after seven days, as stated (in Num 12:15): So Miriam was shut up [outside of the camp] for seven days. Ergo (in Lev 14:2): This shall be the law of the leper (metsora'). The one who proclaims evil (motsi' ra') is the one who finds evil (motse $\left.r a^{\prime}\right){ }^{48}$

The text contains the same kal va-homer (a fortiori)-argument ${ }^{49}$ as does Sifre Numbers. But the focus on Miriam's speech is not that she spoke in private (עצמה) so that nobody could hear her words, but that Moses himself did not hear them because he was "absent" (שלא בפניו). The problem does not seem to be Miriam's speaking before others in general, but the question whether she pronounced her criticism directly to Moses' face. Tanhuma and Sifre Numbers describe Miriam's intention similarly: In both texts her aim is to reconcile Moses with his wife.

48 J.T. Townsend, Midrash Tanhuma: Translated into English with Indices and Brief Notes (S. Buber Recension), vol. II Exodus and Leviticus (Hoboken, N. J.; KTAV, 1997), 263 (slightly modified). Hebrew text: S. Buber, Midrash Tanhuma 2. Shemot, va-yikra, be-midbar, devarim (Israel: Mif'ale sefraim le-yitsu, 1964), 46-47.

$49 \mathrm{Kal} v a$-homer is one of the hermeneutic rules of R. Ishmael. It designates "an argument from the minor premise ( $k a l)$ to the major (homer)." See L. Jacobs and D. Derovan, "Hermeneutics," EncJud ${ }^{2} 9$ (2007): 25-29.

50 Additionally, Moses is called "her beloved (חביבה) brother." That stresses the central meaning of the personal relationship in this problematic episode and further exonerates Miriam. 
Concerning Aaron, Tanhuma explicitly states that he was also afflicted by leprosy (as a punishment), but that he was healed immediately, whereas Miriam had to wait seven days. No reason is given for this unequal treatment. The reason can only be inferred from the text as a whole: Most of the passage speaks about Miriam and her skin disease, not of Aaron. Furthermore, it only discusses and tries to justify Miriam's speaking against Moses, never Aaron's. One can conclude that Aaron's speaking is much less problematic than Miriam's. The last sentence, the conclusion of the argument, expresses this consideration explicitly, using a pun on the term "leprosy" (מצורע): "The one who proclaims evil is the one who finds evil (המוציא רע שמצא רע)." This means, of course, nothing else than that Miriam "proclaimed evil" against Moses, even if the text tries to justify her words and exonerate her. Tanhuma does not openly criticize Miriam. Yet, the biblical text and its traditional explanation lead to the conclusion that her (evil) speaking against Moses requires punishment. The common ideas about women's speaking (not too open, not too much, and in any case subservient) are effective also in this text, although the matter is not addressed directly.

Other midrashim also eventually allude to Miriam's speech in Num 12:1. Leviticus Rabbah 16.1, for example, mentions Miriam's speaking and her punishment in an explanation of Prov 6:17: לשון שקר:

A lying tongue (Prov 6:17). [We know that it is hated by God] from Miriam, as it is written, And Miriam and Aaron spoke against Moses ... And the anger of the Lord was kindled against them (Num 1:1-9). And whence do we know that she was smitten with leprosy? - It is said, And when the cloud was removed from over the Tent, behold, Miriam was leprous, as white as snow (Num 12:10). ${ }^{51}$

This correlation clearly qualifies Miriam's words as mendacious. Deuteronomy Rabbah 6.11 "legitimates" Miriam's slandering words with the general loquacity of women.

All these texts clearly show that female speech was considered problematic in one way or another. Some interpretations are more critical, others rather try to justify Miriam's behavior. All however seem to feel the necessity to explicitly deal with the matter. This is, of course, due to the biblical text, which hints at Miriam's leading role in this episode and permits her to be the only one struck by leprosy. The biblical account is read together with the cultural background of the readers, in this case their ideas about women and men, their behavior, and their speaking. From this perspective, the fact that Miriam alone is punished, or much more severely punished than Aaron, can only be explained by her inappropriate speech. Prophecy, incidentally, is a topic of the biblical episode in Num 12, but rarely of its rabbinic interpretations. Their themes are "slandering" and the "bad tongue."

51 Lehrman, Exodus, 201 (slightly modified). 


\subsection{Miriam's Prophecy in Bavli Megillah 14a-b}

A famous passage in $b$. Meg. 14a-b singles out seven women as a distinct group of prophets. The women who are called נביאה in the Tanakh are not the only ones listed here; ${ }^{52}$ the seven include: Sarah, Miriam, Deborah, Hannah, Abigail, Huldah, and Esther. ${ }^{53}$ The text offers arguments for why each of these women should be considered a female prophet. All of the explanations refer to biblical verses and point to the characteristics of each woman. All of these female prophets say something that could be interpreted as a prediction of the future. In the case of Sarah, Gen 21:12 is quoted, where God orders Abraham to listen to her. This is justified by her other name Iscah (cf. Gen 11:29), which is explained as סכתה: "she discerned by the holy spirit." 54 The holy spirit is also mentioned in the description of the last of the seven women, Esther. The expression "Esther put on her royal robes" (Esth 5:1) "shows that the holy spirit clothed her." 55 Thus, beside prophetic utterance, inspiration by the holy spirit is an important characteristic of a prophet. In the passages about Deborah and Huldah, who bear the title נביאה in the Hebrew Bible, the circumstances of their prophecies are discussed. Hannah prophesied about the royal house of David and Solomon; Abigail predicted David's adultery with Bathsheba. In the case of Miriam, a tradition is quoted that can also be found in $b$. Sotah. ${ }^{56} \mathrm{In}$ both texts, Miriam was called a female prophet because she prophesied Moses' birth and destiny as Israel's savior. All of the prophecies concern men or at least the people of Israel.

The Talmud in Megillah also utters criticism of the female prophets:

R. Nahman said: Haughtiness does not befit women. There were two haughty women, and their names are hateful, one being called a hornet [Deborah] and the other a weasel [Huldah]. Of the hornet it is written, And she sent and called Barak [Judg 4:6], instead of going to him. Of the weasel it is written, Say to the man [2 Kgs 22:15], instead of "say to the king." 57

The Talmud considers the behavior of Deborah and Huldah to be improper: How could a woman order a man to come to her? How can she call the king a mere "man?" This sounds quite disrespectful. Although they are female prophets, they are criticized by the Rabbis, not for their prophecy proper, but for their lack of subservience. Female prophets are accepted, insofar as they, guided by the holy spirit, prophesy about and for men. They are criticized as soon as they question male authority in some way (or even only seem

52 These are Miriam (Exod 15:20), Deborah (Judg 4:4), Huldah (2 Kgs 22:14), Noadiah (Neh 6:14) and the anonymous prophetess mentioned in Isa 8:3.

53 Gen. Rab. 67.9 states that all the matriarchs were female prophets.

54 English translation: M. Simon, The Babylonian Talmud: Seder Moed 3: Megillah (ed. I. Epstein; London: Soncino Press, 1936), 55-232, 82.

55 Simon, Megillah, 85.

56 For more details see below.

57 Simon, Megillah, 85. 
to do so). They are adult women and have to be reproached for their alleged "haughtiness." ${ }^{8}$ As will be shown below, Miriam's prophecy is transposed to her childhood and is thus highly esteemed. Her rebellious nature ${ }^{59}$ is justified by her young age. Therefore, Miriam's prophecy does not challenge the Rabbis and is harmless, like the little girl herself. The passage $b$. Sotah $11 \mathrm{~b}-13 \mathrm{~b}$ includes the same tradition about Miriam's prophecy as $b$. Meg. 14a but has much more to say about her, so that a more comprehensive image of Miriam evolves from this text.

\section{Miriam's Image in b. Sotah $11 b-13 b$}

In the following the clues about Miriam's speaking, scattered throughout the text of $b$. Sotah 11b-13b, mainly in 11b-12a, will be surveyed in order to recreate Miriam's image as a female prophet according to $b$. Sotah. ${ }^{60}$

In Exod 1:15 the Pharaoh tells the Hebrew midwives to kill the male babies and let the female ones live. In this verse the names of the two Hebrew midwives are given: Shiphrah and Puah. The Bavli identifies them as mother and daughter, Jochebed and Miriam, two biblical women occurring in the immediate neighborhood: Exod 2:1 mentions a nameless woman from the tribe of Levi; Exod 2:4 mentions the baby's nameless sister, thus her daughter. Jochebed's name is first mentioned in Exod 6:20 as the mother of Aaron and Moses and a second time in Num 26:59 as the mother of Aaron, Moses, and Miriam. Miriam's name is first mentioned in Exod 15:20. The rabbinic interpretation reads the entire Tanakh, especially the Torah, as one consistent text. ${ }^{61}$ Evidence from different places within Scripture is put together, and different passages are read as enlightening one another. Obvious gaps in the biblical text are filled by interpretation, primarily by reading other biblical texts as intertexts. ${ }^{62}$ In the case of Miriam, all texts where Miriam or the "sister of Moses" is mentioned are connected to each other and read in light of each other.

For the names Shiphrah and Puah respectively, two explanations are given through a play on words. The second explanation for Puah reads: "Another explanation of Pu'ah is that she used to cry out (po'ah) through the holy spirit and say: 'My mother will bear a son who will be the savior of Israel'" ( $b$. So-

58 Simon, Megillah, 85.

59 Cf. Exod. Rab. 1.13 (see below).

60 Hebrew text: Talmud Bavli (Vilna: Romm, 1889/90; repr. Jerusalem: El Hamekoroth, 1957). English Translation: A. Cohen, The Babylonian Talmud: Seder Nashim 3: Nedarim, Nazir, Sotah (ed. I. Epstein; London: Soncino Press, 1936), 275-300.

61 Which is not to say that rabbinic interpretations fail to show ambiguities in the text.

62 Cf. D. Boyarin, Intertextuality and the Reading of Midrash (Bloomington, Ind.: Indiana University Press, 1990), 16-17, who speaks of Midrash as "radical intertextual reading of the canon." This interpretive technique can also be found in the Talmud. 
tah 11b) ${ }^{63}$ Here the tradition about Miriam's prediction of Moses' birth already found in L.A.B. reoccurs in a very short form and without further comment. We are not told anything about the reaction of the parents or other possible listeners.

Another interesting instance is the interpretation of Exod 1:21, where the biblical text states that God "made them [the midwives] houses" (ביעש להם) בתים). The houses are usually interpreted and translated as "families." The Talmud also considers descendants when it maintains that King David is a descendant of Miriam (b. Sotah 11b). To "prove" this, Miriam is identified with diverse women mentioned mainly in the genealogies of $1 \mathrm{Chr} 2$ and 4 . Caleb (cf. Josh 14:6) is made her husband. ${ }^{64}$ But, according to $b$. Sotah 11b-12a, he marries her for higher purposes. The diverse names Miriam is given are at least partly interpreted as the story of her marriage. The name Azubah therefore is supposed to hint at men who had left Miriam. The reason is given by another name: יריעות שהיו פניה דומין ליריעות "Jerioth' - [she was so named] because her face was like curtains," meaning pale (because of her illness) ${ }^{65}$ Also the name Helah is interpreted as referring to illness. The mention of Miriam's illness is motivated by the narrative in Num $12 .{ }^{66}$ In this way, another biblical text about Miriam is read as an intertext of Exod 1-2. The picture of Miriam in Num 12, namely her illness, which in fact is a punishment, is the backdrop of these interpretations. By identifying Miriam in terms of these various names, and their particular explanations, the text characterizes Miriam as complex and multi-faceted. After her prophecy in favor of Moses is recounted, the names caution the readers to the possible results of her speaking against him. The various names remind readers of the dangers of women who speak too much and challenge male authority.

In Exod 1:22, Pharaoh commands his people to kill the Hebrew boys. Immediately following, Exod 2:1 states: "And a man from the house of Levi went ..." Like his wife, Moses' mother, the man is nameless in this passage and is first called Amram in Exod 6:18. The Talmud, as in the case of the women, identifies the nameless man according to Exod 6 and inserts the following story:

A Tanna taught: Amram was the greatest man of his generation; when he saw that the wicked Pharaoh had decreed, "Every son that is born ye shall cast into the river," he said, "In vain do we labor." He arose and divorced his wife. All [the Israelites] thereupon arose and divorced their wives. His daughter said to him, "Father, thy decree is more severe than Pharaoh's; because Pharaoh decreed only against the males whereas thou hast decreed against the males and females. Pharaoh only decreed concerning this world whereas thou hast decreed concerning this world and the World to Come.

63 Cohen, Sotah, 57.

64 Exod. Rab. amplifies this passage considerably (see below).

65 Exod. Rab. also has this explanation. In one textual variant of Exod. Rab., this allusion is changed into a positive statement: יפות כיריעות המשכן - "beautiful like the curtains of the temple."

66 For further discussion see Steinmetz, "Portrait," 43-44. 
In the case of the wicked Pharaoh there is a doubt whether his decree will be fulfilled or not, whereas in thy case, though thou art righteous, it is certain that thy decree will be fulfilled, as it is said: Thou shalt also decree a thing, and it shall be established unto thee! He arose and took his wife back; and they all arose and took their wives back. ${ }^{67}$

This story ascribes an extraordinary authority to Miriam, even vis-à-vis her father. Her behavior is not criticized at all. Noticeably, the source of her authority is not mentioned. Is it God or the spirit? In the first passage about her prophecy (b. Sotah 11b, see above) the holy spirit was explicitly mentioned. Does this mean that Miriam now speaks out of her own authority, or does she remember the former prophecy? Readers, of course, can and probably will connect the two texts and interpret Miriam's words to or against her father as a consequence of her prophecy about Moses' birth. On the other hand, Miriam's words do not allude to a savior for Israel. One cannot easily discern her former prophecy in this second speech. It concerns not only Amram and his wife, but all Israelites, and not only the future savior, but all children to be born. Nevertheless, Miriam's words show wisdom and insight in the divine order of the world. This may qualify them as prophetic. Furthermore, the reunion of her parents is the presupposition for the fulfilment of her former prophecy.

Though quite audacious, Miriam's words fit perfectly into the patriarchal world, because they express her concern for genealogical continuity, one of the most prominent concerns of biblical and rabbinical societies, which is endangered by Amram's divorce. ${ }^{68}$ Family continuity, especially the continuity of the family of the people's leader, in this context also means continuity of the people, of Israel itself. Therefore, although questioning hierarchy and authority, her speech can be accepted by the Rabbis (it is, in fact, created by the Rabbis). ${ }^{69}$ Moreover, Miriam corroborates and strengthens Amram's authority, as she addresses him as righteous. The acceptance of Miriam's words is confirmed by the fact that Amram follows her advice (הלך בעצת בתו). That a man - "the greatest man of his generation" - followed the advice of his little daughter seems extraordinary and corroborates Miriam's authority.

Another passage about Miriam's prophetic speech shows that her prophecy is completely transposed to her childhood. In the interpretation of Exod 2:8, where the Pharaoh's daughter sends the girl to get a nurse for the baby Moses, the Talmud gives the following tradition:

And Miriam the prophetess, the sister of Aaron, took etc. (Exod 15:20). The "sister of Aaron" and not the sister of Moses! - R. Amram said in the name of Rab, and according to others it was R. Nahman who said in the name of Rab: It teaches that she prophesied while she yet was the sister of Aaron only and said: "My mother will bear a

67 b. Sotah 12a; Cohen, Sotah, 60.

68 Steinmetz, "Portrait," 38, identifies this as the midrashic Miriam's primary concern. Steinmetz concentrates on a particular group of stories and omits the midrashim dealing with the well and the song.

69 See also Steinmetz, "Portrait," 50. 
son who will be the savior of Israel." When Moses was born, the whole house was filled with light; and her father arose and kissed her upon her head, saying, "My daughter, thy prophecy has been fulfilled"; but when they cast him into the river, her father arose and smacked her upon her head, saying: "Where, now, is thy prophecy!" That is what is written: And his sister stood afar off to know what would be done to him - what would be the fate of her prophecy. ${ }^{70}$

This interpretation is motivated by the question: Why does the sister stand on the river bank and wait? The biblical text does not answer this question satisfyingly; thus the midrash fills the gap. Again her prophecy is inserted into the narrative. In this story, the question of Miriam's prophecy is focused on the father-daughter-relationship. ${ }^{71}$ Miriam's father judges his daughter's prophecy: At first, he obviously believes her words and kisses her. As the prophecy seems endangered, he reproaches her. Miriam does not react in any way, nor does she speak again, but she waits for the outcome of the events, which, of course, proves her prophetic words to be true. Interestingly, in Exod 15, the father is not even mentioned, and Miriam is only identified in relation to Aaron. ${ }^{72}$ Miriam and even her prophetic speech, which is divinely inspired, are subordinated to her father's authority. This corresponds to the fact that her prophecy is removed from Exod 15, when she is supposed to be an adult, and transferred to her childhood, when she is under her father's authority.

The motif of the parents' disbelief, which is prominent in L.A.B., is lacking here. Yet the fulfilment of the prophecy is not taken for granted. In the present context, this doubt is motivated by the biblical text and answers the question why Miriam looks after the baby on the river. The obvious gap in the narrative is filled by a new, interpretive narrative. This one, in fact, questions the father's authority. Amram does not believe the divine word uttered by his little daughter. On the other hand, his doubt is understandable: The female prophet is his daughter, young and female, whereas authority in ancient Israelite and rabbinic societies is preferably exercised by old(er) men. That his son Moses is put into the river is one more reason to doubt the positive outcome of his daughter's prediction. Thus, this narrative underlines Miriam's prophetic authority on the one hand, yet questions it from the father's perspective on the other hand. Miriam's image remains somewhat ambivalent, but ultimately the text corroborates her status as a reliable female prophet.

The last mention of Miriam in this passage refers to her death and her being a female prophet: "It was called Nebo because three prophets [nebi' im] died there, viz. Moses, Aaron, and Miriam" (b. Sotah 13b). ${ }^{73}$ Miriam is one of the three prophets, without any differentiation from her brothers. Interestingly,

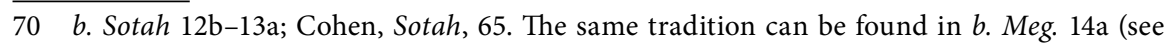
above).

71 In L.A. B. both parents are mentioned.

72 The Talmud and midrash do not deal with Miriam's prophecy in the interpretation of Exod 15.

73 Cohen, Sotah, 71. 
although she dies first, she is mentioned last. This probably reflects a hierarchy of the three siblings assumed by the Rabbis. However, her prophecy is not contested here in any way.

At first sight, $b$. Sotah $11 b-13 b$ creates a very positive image of Miriam as a female prophet. Apart from the doubt her father utters when Moses is put into the Nile, no problems arise from Miriam's prophecy or her criticism of her father's behavior. Yet, some subtle censure is observable, primarily in the tradition of the names, which places her prophecy against the backdrop of Num 12. What is more important is that Miriam's prophecy is restricted to her childhood and subordinated to her father's authority. The concern of her prophecy is identified as continuity of the family and the people, a primary concern in patriarchal societies.

This raises the question of the character of Miriam's prophetic performance, or rather, of its audience. Exodus 15:21 presumes a public appearance. Miriam sings and leads the women's cultic musical performance, which is obviously watched by the other (male) Israelites. In $b$. Sotah $11 \mathrm{~b}-13 \mathrm{~b}$ Miriam is depicted as a little girl, and one might think that the audience is restricted to her parents (and perhaps her brother Aaron). In L. A. B. this is clearly the case: Miriam recounts her dream to her parents. In $b$. Sotah this is not explicitly stated, but can be assumed. Concerning her first prophecy, the context is not clear, because the text is mainly interested in the explanation of the name and thereby the girl's characterization. In the case of her second prophecy, only her father reacts to it. This suggests that the rabbinic authors thought of a private context. Therefore, with the transposition of Miriam's prophecy to her childhood, its public character also disappears, becoming almost unnoticeable.

\section{Miriam's Image in Exodus Rabbah 1.13-22}

Compared to $b$. Sotah, Miriam's image undergoes a change in Exodus Rabbah..$^{74}$ The critical elements are enhanced and at the same time her prophetic authority is further diminished.

As in $b$. Sotah, in the interpretation of Exod 1:15, the names Shiphra and Puah are associated with Miriam and her mother. Exodus Rabbah provides not only two, but a whole list of identifications for each of them. At the beginning, the midrash maintains that Miriam was only five years old, yet her character was apparent in her deeds. So, one explanation of her name Puah is the following:

74 Hebrew text: Shinan, Midrash Shemot Rabbah; English translation: Lehrman, Exodus. The first part of Exod. Rab. was redacted in the $10^{\text {th }}$ century. It used the material from $b$. Sotah, though in a different order, and added to it. It is an exegetical midrash that interprets Exodus 1-10 verse by verse. See Stemberger, Einleitung, 304. 
She lifted up her face against Pharaoh and turned up her nose against him, saying: "Woe unto this man when God comes to exact His retribution." Whereupon Pharaoh became so angry that he sought to slay her. Shiphrah - because she smoothed over (meshapereth) her daughter's words and pacified [the king] for her. For she said to him: "Do you take notice of her? She is only a child and knows nothing." 75

The next explanation of the name Puah - ascribed to R. Hanina, the son of R. Isaac - is:

Puah - because she dared to reprove [literally: lifted up (hofi'ah) her face against] her father. Amram was at that time the head of the Sanhedrin, and when Pharaoh decreed that If it be a son, then ye shall kill him, Amram said that it was useless for the Israelites to beget children. Forthwith he ceased to have intercourse with his wife Jochebed and even divorced his wife, though she was already three months pregnant. Whereupon all the Israelites arose and divorced their wives. Then said his daughter to him: "Your decree is more severe than that of Pharaoh; for Pharaoh decreed only concerning the male children, and you decree upon males and females alike. Besides, Pharaoh being wicked, there is some doubt whether his decree will be fulfilled or not, but you are righteous and your decree will be fulfilled." So he took his wife back and was followed by all the Israelites, who also took their wives back. Hence was she called Puah, because she dared to reprove her father. ${ }^{76}$

This passage is the explanation of Exod 2:1: "And there went a man of the house of Levi, and took to wife a daughter of Levi." The problem underlying the midrashic interpretation is that the biblical text recounts a marriage, but at the same time presumes that the couple already had two children, Aaron and Miriam. Moses, whose birth is told in the passage that follows, is the youngest. The midrash explains this discrepancy or gap through the quoted narrative: Amram divorced and then took back his wife, a re-marriage, so to speak. Thus it is possible that the newborn boy in Exod 2:2 had two older siblings.

In comparison with $b$. Sotah, a part of Miriam's speech is left out in this passage ${ }^{77}$ and the last sentence is added, an explicit disapproval of Miriam's speech towards her father. The sentence פועה שהופיעה פנים כנגד אביה ("Puah, because she dared to reprove her father") frames this interpretive unit. Whereas in $b$. Sotah this episode is told without any evaluation, in Exod. Rab. there is an explicit judgement of Miriam: She "lifts her face against her father" as well as against Pharaoh. Her words are considered inappropriate. What is the reason for this negative appraisal? Miriam, a girl of just five years, violates hierarchies and authorities through her speeches. She speaks against elder men: the king and her father. She acquires authority for herself. Yet, there is a difference between the two cases: In her words against Pharaoh, she invokes God. Her mother defends her, pointing to her youthful age. Moreover, this reticence is

75 Exod. Rab. 1.13; Lehrman, Exodus, 17.

76 Exod. Rab. 1.13; Lehrman, Exodus, 17-18.

77 Miriam's statement about this world and the world to come only occurs in the Talmud and is omitted in Exod. Rab. 1.13: "Pharaoh only decreed concerning this world whereas thou hast decreed concerning this world and the World to Come." See above, b. Sotah 12a. 
in accord with the midwives' nonviolent resistance to Pharaoh's decrees. ${ }^{78}$ In her words to her father, there is no reference to God. Although her father acts according to her admonition, the interpreter criticizes her speech. Moreover, one should bear in mind that Miriam's words in both cases are in favor of the Israelites' (and Moses') procreation. The rabbinic image of Miriam as a female prophet is indeed ambivalent in this case. They deprive her speech of divine legitimation insofar as they keep silent about God's assistance.

The text that follows, Exod. Rab. 1.15, praises the good deeds of the midwives, their generous help for children and mothers, and their prayers on behalf of disabled children or dying mothers. Helping, caring, mothering, praying - these are understood as typically female behaviors and therefore are praised, and in no way debated..$^{79}$ The "houses" God made for the midwives according to Exod 1:21 are interpreted in the same manner as in the Talmud and, again, amplified by further names and biblical verses. In this context, several names of Miriam are given and interpreted. Among these are "Helah and Naarah," which are connected to Miriam's illness. Though $b$. Sotah also speaks of an illness of Miriam, Exod. Rab. is more elaborate on this point:

... and why was she called "Helah and Naarah?" Because she was ill (halthah), but she bestirred herself (nin'arah $)^{80}$ in spite of her illness and the Lord restored her to youth (na'aruth). "And Naarah bore him" (1 Chr 4:5). After she recovered from her illness, she bore him children, Ahuzam and Hepher. ${ }^{81}$

Miriam's concern for children seems to be the dominant perspective in this passage. Yet, the allusion to Num 12 brings her slanderous words against Moses to the readers' minds.

Toward the end of this passage, the name אחרחל "Aharhel" (cf. 1 Chr 4:8) is explained as אחר חל "after (her) with dance" by quoting Exod 15:20: The women went after her with timbrels and with dances. There is no word about her singing, i. e., speaking.

Exod. Rab. 1.22 interprets Exod 2:4: "And his sister stood afar off." As in the Talmud, her prophecy about Moses' birth is introduced here. In comparison to $b$. Sotah, there are a few small changes in the text:

Why did Miriam stand afar off? R. Amran in the name of Rab said: Because Miriam prophesied, "My mother is destined to give birth to a son who will save Israel"; and when the house was flooded with light at the birth of Moses, her father arose and kissed her head and said: "My daughter, thy prophecy has been fulfilled." This is the meaning of: And Miriam the prophetess, the sister of Aaron, took a timbrel (Exod

78 Steinmetz, "Portrait," 55-57, points to Miriam's rebellious nature, which is also expressed in other instances in the Midrash.

79 Miriam's caring or rather nourishing character is also central to the tradition about the well, cf. Lev. Rab. 13.20. Interestingly, in this tradition Moses is the warrantor of the manna. This underscores also his "motherly" role for Israel. Cf. also y. Ta'anit 1.2; Eccl. Rabb. 7.1.

80 Shinan's text reads ונערה מחוליה, "she stirred from her illness."

81 Exod. Rab. 1.17; Lehrman, Exodus, 24. 
15:20); “The sister of Aaron," but not of Moses? - [She is so called] because in fact she said this prophecy when she was yet only the sister of Aaron, Moses not having been born yet. Now that she was casting him into the river, her mother struck her on the head, saying: "My daughter, what about thy prophecy?" This is why it says: "And his sister stood afar off," to know what would be the outcome of her prophecy. ${ }^{82}$

In this version it is Miriam's mother who utters doubt about the prophecy. The reason may be that she is the one who put the basket onto the river. In this case, Miriam is subordinated to both parents' authority, not only her father's.

The overall impression of the textual differences between $b$. Sotah and Exod. $R a b$. shows a clear tendency: Although Miriam is valued as the midwife Puah, and her father is explicitly said to have "followed his daughter's advice" (Exod. Rab. 1.19), ${ }^{83}$ criticism of Miriam is not lacking in Exod. Rab. Both perspectives, the respect for her prophecy and the criticism of her disregard for male or paternal authority, are juxtaposed in this text.

\section{Conclusion: Miriam's Image as a Female Prophet}

There are three speeches attributed to Miriam by the rabbinic texts: her words to Pharaoh, which can only be found in Exod. Rab., her prophecy about Moses' birth, and the admonition of her father. All three are in some way prophetic in character. They contain predictions, which is typically prophetic. ${ }^{84}$ Her speeches imply knowledge and insight. Yet, God's spirit is mentioned only once. ${ }^{85}$ The prediction concerning the birth of Moses is explicitly called a prophecy. Miriam's admonition of her father stands in direct connection with this prophecy: If Amram divorces his wife, what will become of her prophecy?

Miriam's three speeches are differently valued. The speech against Pharaoh is subversive, as the midwives' behavior is subversive. It may be read as an expression of the midwives' non-violent resistance against Pharaoh's decree. In this case, Miriam is supported by her mother, who defends her by pointing to her youthful age. Miriam's resistance seems to be justified, as it refers to God's will and disputes the Pharaoh's decrees against the Israelites' procreation and continuity.

The story about the prophecy concerning Moses is ambivalent. B. Sotah and Exod. Rab. do not mention that the parents did not believe (as L.A.B. does). But her father (or mother) reacts according to the respective situation: He re-

82 Exod. Rab. 1.22; Lehrman, Exodus, 28.

83 This does not necessarily mean that he believed her prophecy. It is also possible that he just thought her advice to be reasonable.

84 Also her advice to her father implies a prediction, insofar as Miriam tells him that his decree will be fulfilled (see above p. 349-50).

85 The divine provenance of a prophet's words is crucial for his/her credibility and reputation. 
joices at the moment of Moses' birth and is doubtful in the moment of his exposure on the river. Miriam's prophecy is precarious, its fulfilment far from certain.

Miriam's admonition of her father is presented as reasonable. The readers are informed explicitly that he followed his daughter's advice. Yet, Exod. Rab. adds criticism to this story. Miriam's prophetic authority is estimated in relation to her father's (or her parents') authority. Although Miriam's prophetic speaking is accepted, the redactors at least want to mention that this is not the usual order. The Sifre to Num 12:1 makes a statement concerning Miriam's speaking before Aaron. Her speaking potentially calls her father's or brother's authority into question.

What seems perhaps even more important is the transposition of Miriam's prophecy from Exod 15 to Exod 2. In the midrashic interpretation of Exod 15, the focus is on Moses. Miriam's prophecy is not discussed there, neither is her song treated as a prophecy. ${ }^{86} \mathrm{To}$ the contrary, it is entirely neglected. The shift of Miriam's prophecy to Exod 2, in the context of her and her brothers' childhoods, and especially her mother's words about Miriam's young age, together serve to relativize her prophecy. Because Miriam is presented as a child, not knowing anything, the value of her speech is diminished; in this way the text further diminishes Miriam's role as prophet and her role in the entire Exodus story. As Steinmetz points out, the Rabbis do not ascribe a leadership role to Miriam; she "is cast by the rabbis in the mold of the biblical matriarchs." ${ }^{87}$ The focus of Miriam's prophecy, on family affairs and the birth of children, only serves to further reduce her prophetic and authoritative status.

The identification of Miriam as the midwife Puah in $b$. Sotah and Exod. $R a b$. equally fits this underlying intention to limit Miriam to the world of family and children. A midwife's task is focused on women's issues and family affairs. Midwives are supposed to be motherly, and they are described accordingly. Miriam's identification with Puah hence restricts her role and importance vis-à-vis Exod 2 and 15 and instead highlights her caring and motherly character.

In the interpretations of Num 12 (in Sifre Zuta, Sifre Numbers, Tanhuma, and others), which address Miriam's actions as a grown woman, her speech is no longer treated as unproblematic. Now she is criticized for it, and her speaking is restricted and at best excused. Moreover, her speaking is treated as "slandering" and not as prophecy (or even as a discussion about prophecy). These texts do not discuss whether Miriam is a female prophet but instead focus on her relationship with Moses. They clearly show that a woman's speech

86 Fischer's understanding of the song as Miriam's prophecy and of prophecy as mediation between YHWH and Israel (see above section 3.1) is not be observed in the rabbinic texts. The rabbinic understanding of prophecy rather corresponds to the idea of prophecy as prediction, as, for instance, reflected in L.A.B. (see ch. 3.1).

87 Steinmetz, "Portrait," 58. 
may be problematic. Without contributing to Miriam's image as a prophet, ${ }^{88}$ they question by means of allusion Miriam's authority to speak at all.

The statements about Miriam's prophecy in Exod. Rab., amplifying already existing traditions, are a subtle criticism of Miriam's prophetic speech, of female prophetic speech, and of its authority in general. Miriam's image as a female prophet is ambivalent: On the one hand, her prophecy is accepted, as supported by divine authority and as corroborating patriarchal society structures. On the other hand, her prophecy, being that of a woman, is regarded as a challenge to male authority. It is therefore restricted to Miriam's childhood and presented ambivalently. Whereas $b$. Sotah displays appreciation for Miriam's prophecy, Exod. Rab. reduces her authority considerably and restricts her much more to the "female" sphere of bearing and caring for children, which here includes predicting the birth of a child. Her reward, according to the Rabbis, is her future offspring, David. Through this literary process, Miriam has been transformed from a prophetic (if not undisputed; see Num 12) participant in leadership to one of the great and famous mothers in Israel. Put into this frame, her speaking as a female prophet is no longer a threat to her male counterparts, either Moses or his descendants, the sages. ${ }^{89}$

88 Neither is an image of Miriam of a visionary, as Tervanotko suggests for Num 12 and L.A.B. (see n. 40), visible in the rabbinic texts.

89 Modern Jewish women have responded to this literary transformation by reclaiming the authority of midrashic practice as an opportunity for feminist expression. See E. Frankel, The Five Books of Miriam: A Women's Commentary on the Torah (New York: HarperCollins Publisher, 1998), 110. 